\title{
Enzymatic Reduction of Methionine Sulfoxide. In Vitro Experiments with Rat Liver and Kidney
}

\author{
Christian Aymard, Lisette Seyer and Jean-Claude CheFtel \\ Laboratoire de Biochimie et Technologie Alimentaires, Université des Sciences et Techniques \\ du Languedoc, Place Eugène Bataillon, 34060 Montpellier Cédex, France
}

Received March 15, 1979

\begin{abstract}
Direct experimental evidence is given for the presence of methionine sulfoxide reducing enzymatic activity in rat liver and kidney. Experiments were performed with $\mathrm{L}\left(\mathrm{U} \cdot{ }^{14} \mathrm{C}\right)$ methionine RS sulfoxide, incubated with liver or kidney homogenates or subcellular fractions, the formation of methionine being determined by ion-exchange chromatography and radioactivity measurement. The methionine sulfoxide reducing activity is thermolabile and enhanced by the addition of NADH to the incubation medium. The subcellular distribution patterns of the enzymatic activities from the liver and from the kidney are quite different.
\end{abstract}

$S$-oxidized sulfur amino acids are fairly widespread: free $S$-methylcysteine-sulfoxide, $S$ allylcysteine-sulfoxide and other $S$-alkylcysteine-sulfoxides are found in various Cruciferae and Lilliaceae ${ }^{1)}$; free $N$-methyl methionine sulfoxide and methionine sulfoxide are present in some red algae ${ }^{2)}$; methionine sulfoxide has been identified in collagen and basement membrane. ${ }^{3)}$ Food proteins may contain significant amounts of protein-bound methionine sulfoxide, especially when the food has been submitted to an oxidizing treatment (such as bleaching, detoxifying or sterilizing with hydrogen peroxide; hot air drying) or to oxidative deterioration reactions (presence of lipid peroxides, quinones). ${ }^{4,5)}$

The biological activity- or toxicity- of aminoacid sulfoxides has been little studied, except in the case of methionine sulfoxide: the nutritional availability of the 2 stereoisomers of L-methionine sulfoxide and that of residues of methionine sulfoxide in some proteins have been assessed in young rats and chicks and found to be $70 \sim 100$ per cent that of methionine. ${ }^{(27)}$ The metabolism of methionine sulfoxide has also been studied in rats in vivo or with perfused liver (Finot and Aymard, unpublished results, Finot et $a l^{18)}$ Since free methionine sulfoxide cannot be utilized as such for protein synthesis, ${ }^{19}$ ) these various experiments suggest that it is reduced into methio- nine in vivo.

While the enzymatic reduction of free methionine sulfoxide is well documented in bacteria, yeast and higher plants, ${ }^{20 \sim 25 ;}$ it has never been experimentally demonstrated in animals. In the present paper, direct experimental evidence is given for the presence, in rat liver and kidney, of an enzyme with methionine sulfoxide reducing activity.

\section{MATERIALS AND METHODS}

Chemicals were of the finest grades available from Boehringer (Mannheim), or Merck and used without further purification.

L(U. $\left.{ }^{14} \mathrm{C}\right)$ methionine ( $\geq 285 \mathrm{mCi} / \mathrm{mmol}$ ) was purchased from the Radio-Chemical Centre, Amersham, England. Conversion to the sulfoxide derivative was performed with hydrogen peroxide according to Sysak et al. ${ }^{20)}$ No attempt was made to separate the two enantiomers resulting from the chirality of the sulfur atom in the sulfoxide.

Male Sprague-Dawley rats (OF-A strain, purchased from Iffa-Credo, 69210 L'Arbresle-France), weighing $60 \pm 5 \mathrm{~g}$ were fasted overnight before experimentation. Liver and kidney homogenates were prepared using a Thomas glass-teflon homogeneizer and 8 volumes of a cold $0.25 \mathrm{M}$ sucrose-potassium phosphate buffered $(0.05 \mathrm{M}, \mathrm{pH} 7.4)$ solution. Subcellular particles were obtained by centrifugation of the homogenates: $800 \mathrm{~g}$ $10 \mathrm{~min}, 8,500 \mathrm{~g}-10 \mathrm{~min}$ (Sorvall $\mathrm{RC} 2 \mathrm{~B}$ centrifuge); $145,000 \mathrm{~g}-1 \mathrm{hr}$ (fixed-angle rotor in a Beckman L575 centrifuge).

Incubation of $\mathrm{L}\left(\mathrm{U} \cdot{ }^{14} \mathrm{C}\right)$ methionine sulfoxide with homogenates (or subcellular particles resuspended in 
the same sucrose phosphate buffered solution used for homogenization) was performed as follows:

L(U. $\left.{ }^{14} \mathrm{C}\right)$ methionine sulfoxide: 100 to $300 \mathrm{nCi}$ with a total concentration of methionine sulfoxide varying from $0.29 \mathrm{~mm}$ to $2.7 \mathrm{~mm}$, obtained by adding non labelled methionine sulfoxide.

$\mathrm{NADH}: \quad 0,0.5$ or $1 \mathrm{~mm}$.

Protein content in each assay-tube: $3 \sim 25 \mathrm{mg}$, in a final volume of $1.5 \sim 1.8 \mathrm{ml}$.

Incubations were usually performed for $3 \mathrm{hr}$, at $25^{\circ} \mathrm{C}$. The incubation was stopped by adding a $20 \%(\mathrm{w} / \mathrm{v})$ sulfosalicylic acid (SSA) solution in the incubation mixture to obtain a $5 \%(\mathrm{w} / \mathrm{v})$ final concentration. After a first centrifugation $(30,000 \mathrm{~g}-10 \mathrm{~min})$, the pellet was resuspended with $1 \mathrm{ml}$ of a $5 \%$ (w/v) SSA solution, centrifuged again in the same conditions and the supernatants were pooled for the determination of the radioactivity associated to methionine and to methionine sulfoxide.

Methionine and methionine sulfoxide were separated by the two following methods:

a) thin-layer chromatography (TLC), using $0.1 \mathrm{~mm}$ cellulose plates (Merck) and $\mathrm{CHCl}_{9}, \mathrm{MeOH}, 17 \%$ $\mathrm{NH}_{4} \mathrm{OH}(3: 6: 1)$ as solvent. Radioautography of the plates (Kodak Kodirex film) allowed identification and semi-quantitative determination of radioactive methionine formed ( $R f$ methionine: $0.63, R f$ methionine sulfoxide: 0.33 ).

b) ion-exchange chromatography on sulfonated polystyrene $C_{2}$ chromobeads (Technicon), in a $25 \times$ $0.6 \mathrm{~cm}$ glass column, thermostated at $60^{\circ} \mathrm{C}$. Differential elution was achieved at a $0.8 \mathrm{ml} \cdot \mathrm{min}^{-1}$ flow rate by a $\mathrm{pH} 3.8-0.2 \mathrm{M}\left(\mathrm{Na}^{+}\right)$citrate buffer. Methionine sulfoxide and methionine are completely separated (elution times 12 and $21 \mathrm{~min}$, respectively).

Radioactivity associated with methionine and methionine sulfoxide was determined in the column effluents by liquid scintillation (Intertechnique SL30 spectrometer), using "Instagel" scintillation cocktail (Packard Instrument). For insoluble samples (centrifugation pellets), a solubilization step was accomplished with "Lumasolve" (Lumac Systems A.G., Basel, Switzerland).

Protein determination was performed by a modified Lowry procedure. ${ }^{27)}$

Results are expressed either as pmol of methionine produced, using for calculation the initial specific radioactivity of methionine sulfoxide, or as per cent of conversion of methionine sulfoxide to methionine:

$$
\frac{\mathrm{dpm} \text { (methionine) }}{\mathrm{dpm} \text { total initial radioactivity }} \times 100 \text {. }
$$

\section{RESULTS AND DISCUSSION}

\section{Determination of labelled methionine and methionine sulfoxide}

More than $99 \%$ of the initial radioactivity introduced in all incubation assays as labelled methionine sulfoxide was recovered in the TCA supernatants, while less than $1 \%$ of the initial radioactivity is found in the TCA pellets (direct measurements after dissolution of the pellets in "Lumasolve").

When methionine and methionine sulfoxide were separated by ion-exchange chromatography of the TCA supernatants, at least $98 \%$ of the radioactivity of the sample submitted to the chromatography could be recovered in the two fractions corresponding to the elution times of methionine sulfoxide and methionine, (as checked in more than 80 chromatographic assays).

The following control was made concerning the radioactivity attributed to methionine: when the TCA supernatant was submitted to mild oxidation with hydrogen peroxide $\left(\mathrm{H}_{2} \mathrm{O}_{2}\right.$ $1.5 \mathrm{M}, 35^{\circ} \mathrm{C}, 2 \mathrm{hr}$ ) before ion-exchange chromatography, the radioactivity of the material previously eluted in the peak of methionine was quantitatively recovered in the peak of methionine sulfoxide. This control, repeated in 5 experiments was taken as a proof that radioactive methionine has indeed been formed in the incubation mixture.

\section{Enzymatic reduction of methionine sulfoxide}

The results of several experiments with liver and kidney homogenates are given in Table $I$. Results are expressed 1) as pmol of methionine formed per assay and per $\mathrm{mg}$ of protein in the assay, and 2) as per cent of initial methionine sulfoxide reduced into methionine. When data were obtained in the same experimental conditions but with separate homogenates from 6 rats, the mean and standard deviation are indicated : a broad range of variation can be noted.

It can also be seen in Table I that the extent of methionine formation is strongly enhanced when NADH is added to the incubation mixture, especially in the case of liver homogenates. No reduction of methionine sulfoxide occurs when the liver or kidney homogenates are submitted to a thermal treatment $\left(95^{\circ} \mathrm{C}, 15 \mathrm{~min}\right)$ 
Table I. Formation of Methionine after Incubation $\left(3 \mathrm{hr}, 25^{\circ} \mathrm{C}\right)$ of L.(U $\left.{ }^{14} \mathrm{C}\right)$ METHIONINE SUlfoxide WITH LIVER OR KIDNEY HoMOgENATES

Results are expressed in pmol* of formed methionine per mg of protein (and as per cent of reduction of methionine sulfoxide)

\begin{tabular}{|c|c|c|c|c|c|c|c|}
\hline \multirow{4}{*}{$\begin{array}{l}\begin{array}{c}\text { Concentration of } \\
\text { added NADH }\end{array} \\
\frac{0}{1}\end{array}$} & \multicolumn{3}{|c|}{ Liver } & \multicolumn{4}{|c|}{ Kidney } \\
\hline & \multicolumn{7}{|c|}{ Initial concentration of methionine sulfoxide } \\
\hline & $0.29 \mathrm{~mm}$ & \multicolumn{2}{|c|}{$2.9 \mathrm{~mm}$} & \multicolumn{2}{|c|}{$0.29 \mathrm{~mm}$} & \multicolumn{2}{|c|}{$2.9 \mathrm{mM}$} \\
\hline & $200 \pm 95(0.9 \%)$ & 1,700 & $(0.8 \%)$ & $310 \pm 135$ & $(1 \%)$ & 2,640 & $(0.9 \%)$ \\
\hline $0.5 \mathrm{mM}$ & $320 \pm 115(1.5 \%)$ & & & $830 \pm 360$ & $(2.7 \%)$ & & \\
\hline $1 \mathrm{~mm}$ & $800 \quad(3.7 \%)$ & $\begin{array}{r}3,300 \\
95 \\
\text { (heat in } \\
\text { contro }\end{array}$ & $\begin{array}{l}(1.6 \%) \\
(0.04 \%) \\
\text { ated } \\
\mathrm{C}, 15 \mathrm{~min})\end{array}$ & 660 & $(2.1 \%)$ & $\begin{array}{r}4,950 \\
55 \\
\text { (heat in } \\
\text { control }\end{array}$ & $\begin{array}{l}(1.6 \%) \\
(0.02 \%) \\
\text { ivated } \\
\mathrm{C}, 15 \mathrm{~min})\end{array}$ \\
\hline
\end{tabular}

* mean value and standard deviation from 6 experiments with homogenates from different rats.

prior to incubation.

Preliminary results with kidney homogenates indicate that the reduction of methionine sulfoxide increases linearly with incubation time up to $6 \mathrm{hr}$ and is multiplied by 1.6 when incubation is performed at $37^{\circ} \mathrm{C}$ rather than at $25^{\circ} \mathrm{C}$. Such effects were much less marked in the case of liver homogenates.

It was also found that NADPH seemed less active than NADH in enhancing the extent of methionine sulfoxide reduction in liver or kidney homogenates. These data indicate that rat liver and kidney contain an enzymatic system able to reduce methionine sulfoxide.

\section{Subcellular distribution of enzymatic activity}

Liver and kidney homogenates were submitted to a classical subcellular fractionation by differential centrifugation. The resulting four fractions (cell debris, membranes and nuclei; mitochondria; microsomes; cytosol) were analyzed for their capacity to reduce methionine sulfoxide. Results from three independant experiments (3 rats) are presented in Table II. The enzymatic activity in each subcellular fraction is expressed as a per cent of the enzymatic activity in the whole liver or kidney homogenate. The protein contents of subcellular fractions are also reported and indicate some variation in the fractionation of liver homogenate within the three experiments. The enzymatic activity of some subcellular fractions appears to vary widely and only 30 to $60 \%$ of
Table II. Subcellular Distribution of the Methionine Sulfoxide Reducing ACtivity in Rat Liver aND KIDNEY

\begin{tabular}{|c|c|c|c|c|c|}
\hline & & $\begin{array}{l}\text { Enzyn } \\
\text { tivity } \\
\text { in the } \\
\text { sue hor }\end{array}$ & $\begin{array}{l}\text { tic ac- } \\
\text { of that } \\
\text { hole } \\
\text { genate). }\end{array}$ & $\begin{array}{l}\text { Protein } \\
\text { (\% of } \\
\text { the who } \\
\text { homog }\end{array}$ & $\begin{array}{l}\text { ontent } \\
\text { at in } \\
\text { tissue } \\
\text { late). }\end{array}$ \\
\hline Subcellular & fraction & Liver* & dney** I & Liver* $\mathrm{K}$ & lney** \\
\hline Cell debris, & exp. 1 & 17 & 26 & 37 & 37 \\
\hline membranes, & $\exp .2$ & 6 & 26 & 45 & 31 \\
\hline nuclei & exp. 3 & 21 & 24 & 24 & 36 \\
\hline Mito- & exp. 1 & 2 & 4.5 & 4 & 6 \\
\hline chondria & $\exp .2$ & 2.5 & 3 & 5.7 & 6 \\
\hline & exp. 3 & 2 & 3 & 4.5 & 6.5 \\
\hline Micro- & exp. 1 & 1.5 & 1.9 & 6 & 5 \\
\hline somes & exp. 2 & 0.5 & 0.7 & 2.5 & 4.5 \\
\hline & exp. 3 & 0.5 & 1 & 2 & 4 \\
\hline & exp. 1 & 38 & 3 & 27 & 30 \\
\hline Cytosol & $\exp .2$ & 22 & 4.5 & 29 & 22 \\
\hline & exp. 3 & 14 & 17 & 19 & 28 \\
\hline
\end{tabular}

* Average enzymatic activity and protein content of the 3 liver homogenates: $400 \mathrm{pmol}$ of formed methionine $/ \mathrm{mg}$ protein; $13 \mathrm{mg}$ protein $/ \mathrm{ml}$.

** Average enzymatic activity and protein content of the 3 kidney homogenates: 730 pmol of formed methionine/mg protein; $10.5 \mathrm{mg}$ protein/ $\mathrm{m}$ !.

the total kidney or liver activity can be recovered in the corresponding fractions. It will be necessary to further control the fractionation process with marker enzymes. It is nevertheless apparent that the liver enzymatic activity is localized mainly in the cytosol (with a specific activity up to $\times 1.4$ that found in the homogenate), while the kidney enzymatic 
activity appears to be mainly associated with the cell membranes and nuclei. These results, together with the data given in the preceeding paragraph, suggest that there are differences between the methionine sulfoxide reducing activities present in the liver and in the kidney.

Acknowledgments. We are grateful to Dr. J.L. Cuq for helpful discussions. We wish to acknowledge the expert technical assistance of Mrs. E. Raulet.

This study has been supported in part by the Centre National de la Recherche Scientifique, Paris (ERA n ${ }^{\circ}$ 614) and by the Délégation Générale à la Recherche Scientifique et Technique (contract $n^{\circ}$ 78.7.1065).

\section{REFERENCES}

1) S. F. Tsuno, K. Murakami and S. Kikumoto, Vitamins, 20, 93 (1960).

2) K. Miyazawa and K. Ito, Bull. Jpn. Soc. Sci. Fish., 40, 655 (1974).

3) V. Odell, L. Wegener, B. Peczon and B. G. Hudson, J. Chromatogr., 88, 245 (1974).

4) J. L. Cuq, P. Besançon, L. Chartier and C.Cheftel, Food Chem., 3, 85 (1978).

5) C. Cheftel, in "Food Proteins," ed. by J.R. Whitaker and S. R. Tannenbaum, Avi Publishing Company, Westport, 1977, p. 401.

6) M. A. Bennett, Biochem. J., 33, 1794 (1939).

7) L. R. Njaa, Br. J. Nutr., 16, 571 (1962).

8) D. S. Miller and P. Samuel, Proc. Nutr. Soc., 27, $21 \mathrm{~A}$ (1968).
9) G. M. Ellinger and R. Palmer, ibid., 28, 42A (1969).

10) S. A. Miller, S. R. Tannenbaum and A. W. Seitz, J. Nutr., 100, 909 (1970).

11) D. S. Miller and P. D. Samuel, J. Sci. Food Agr., 21, 616 (1970).

12) G. H. Anderson, G. S. K. Li, J. D. Jones and F. Bender, J. Nutr., 105, 317 (1975).

13) G.H. Anderson, D.V.M. Ashley and J.D. Jones, ibid., 106, 1108 (1976).

14) L. B. Sjöberg and S. L. Bostrom, Br. J. Nutr., 38, 189 (1977).

15) D. D. Kuzmicky, G. O. Kohler, H. G. Walker and B. D. Mackey, Poultry Sci., 56, 1560 (1977).

16) A. V. Gjøen and L. R. Njaa, Br. J. Nutr., 37, 93 (1977).

17) G. M. Ellinger, Ann. Nutr. Alim., 32, 281 (1978).

18) P.A. Finot, E. Magnenat, F. Mottu and E. Bujard, ibid., 32, 325 (1978).

19) E. Lemoine, Eur. J. Biochem., 4, 213 (1968).

20) J. Touzetich, Anal. Biochem., 73, 290 (1976).

21) J. O. Lampen, M. J. Jones and A. B. Perkins, Arch. Biochem., 13, 33 (1947).

22) T. L. Sourkes and Y. Trano, ibid., 19, 321 (1952).

23) P. P. Cleary and D. Dykhnizen, Biochem. Biophys. Res. Com., 56, 629 (1974).

24) S. Black, E. M. Harte, B. Hudson and L. Wartofsky, J. Biol. Chem., 10, 2910 (1960).

25) R. C. Doney and J. F. Thompson, Biochim. Biophys. Acta, 124, 39 (1966).

26) P. K. Sysak, C. S. Foote and T. Y. Ching, Photochem. Photobiol, 26, 19 (1977).

27) B. Fiszer, Bull. Soc. Chim. Biol., 46, 403 (1964). 